\title{
Liquid soap based on soapstock obtained by neutralizing oils with selective solvents
}

\section{Petik I. ${ }^{1}$, Petik P. ${ }^{2}$, Fediakina Z. ${ }^{3}$}

Ukrainian research institute of oils and fats of the NAAS, Ave. Dziuba, 2a, Kharkiv, 61019, Ukraine; e-mail: 1igor171984@gmail.com; 2direktor.fatoil@gmail.com; 3pererobka.fatoil@gmail.com

The purpose. To gain the information on solubility of salts of fatty acids (soaps) triacylglycerols of some oils in the composition of neutralizing solution of the justified componental composition (water : ethanol : glycerin in ratio of 30:30:40) and also to determine extent of increase of such solubility in comparison with the control dissolvent used in contemporary technique of neutralization of oils and fats - water. Methods. Salts of fatty acids (soap) are gained by saponification of samples of refined sunflower, palm-kernel, coconut oils, and also of some fatty acids by sodium hydroxide, secretion of fatty acids from a mixture and their further saponification. To plan experiments and process data they used mathematical methods and software packages Microsoft Excel and Statistica. Results. Solubility of the gained sodium salts by stearin, palmitic, myristic, lauric, oleic, linoleic and linolenic fatty acids in 3-component neutralized solution is probed at various temperatures. Limiting solubility of sodium salts (soaps) of palm stearine, palm, coconut, palm-kernel oils, palm olein, sunflower and soya oils in neutralized solution from temperature is probed. Conclusions. Recommendations on solubility of sodium salts of fatty acids and their mixtures in neutralized solution are justified, namely: limiting solubility of salts of the indicated fatty acids and their mixtures containing in these oils in neutralized solution at the temperature of $60-65^{\circ} \mathrm{C}$ vary within the limits $25-47 \%$; limiting solubility of soaps of fatty acids in the set temperature range in neutralized solution exceeds those in water in 2,5-4,7 times. They offered to use concentrated soap stocks after neutralization of oils and fats in neutralized solution of the justified contents after the further machining as liquid toilet soap. And density of soap stock in it (in count on fatty acids) should make about $20 \%$ (according to demands of normative documentation on liquid soap).

Key words: salts of fatty acids, soap-alkali solution, surface tension, solubility, liquid soap.

https://doi.org/10.31073/agrovisnyk201901-11

Formulation of the problem. The oil and fat industry in our country works in conditions of rising raw material and energy resource costs. The current market conditions practically exclude the sale of unrefined oils and fats, therefore the development of proposals for the intensification of refining processes is relevant.

The process of refining oils and fats in the soap-alkaline medium is common in the industry and is considered to be effective. However, this technology has a number of shortcomings. One of them is connected with the limitation of the overall speed of the process by the coalescence stage of drops of refined oil (fat) at the boundary of the phase distribution. Almost on the border of the distribution of refined oil (fat) and soap-alkaline solution, an emulsion layer is formed, which causes the oil (fat) to be reduced, and to eliminate the emulsion layer, interrupt the process to remove this layer. Another disadvantage of the neutralization method in the soap-alkaline medium is the formation of diluted soapstocks, which require further concentration by evaporation under vacuum. Soapstocks in the fat processing industry are called dents, which are formed as a result of alkaline refining of vegetable oils and fats. The total fat content of soapstocks with a continuous method of neutralizing oils and fats in the soap-alkaline medium is $10 \%$ or more; neutral triacylglycerols usually make up $70 \%$ of the total fat content of soapstock, that is, the soap content in soapstone is about $3 \%$ [15].

In connection with the above, the actual solution to the issues of rational ways of obtaining a high quality product - neutralized oil (fat), maximizing the resource base of production and obtaining concentrated soapstocks, which practically do not contain neutral fat, whose processing will be significantly facilitated [6, 7]. 
In $[8,10]$, the quantitative dependences of the surface tension and the density of samples of the base of the neutralizing solution on the concentration of the components (water, ethanol and glycerol) were determined, and the optimal composition with respect to the surface tension and the base density of the neutralizing solution for oils (fats) was substantiated. These developments will increase the efficiency of neutralizing oils in the soap-alkaline medium, namely increase the concentration of soapstocks and virtually eliminate the content of neutral fat in them.

The developed basis for a neutralizing solution besides water contains ethanol and glycerol, which makes it much more expensive than water, which is traditionally used in this technology. Proceeding from this, there is a question of determining the ways of using soapstocks after the neutralization of oils (fats) in the basis of the neutralizing solution. It is proposed to use concentrated soapstocks after neutralization of fats in the water-glycerol-ethanol system after further treatment as a liquid toilet soap [8, 9].

The purpose and main objectives of the study. In accordance with the foregoing, the purpose of the study is to obtain information on the solubility of salts of fatty acids (mils) of triacylglycerols of a number of oils in the basis of a neutralizing solution of the substantiated component composition (water: ethanol: glycerol in the ratio of 30: 30:40), and also the determination of the degree of increase of this solubility in compared to the control solvent used in the modern technology of neutralizing oils and fats - water.

In order to achieve the research goal, the following problems need to be solved: the determination of the marginal solubility of fatty acid salts of triacylglycerols in a number of oils in a neutralizing solution of a substantiated composition from the dissolution temperature; a proposal to use soapstocks after neutralizing oils and fats in a neutralizing solution of a reasonable composition.

Materials and methods of research. The following materials were used for research:

- sunflower oil according to DSTU 4492:2005;

- coconut oil according to DSTU 4562:2006;

- palm oil according to DSTU 4563:2006;

- palm stearin according to DSTU 4439:2005;

- palm olein according to DSTU 4438:2005;

- stearic acid according to DSTU 6024:2008;

- oleic acid according to DSTU 4830:2007;

- palmitic acid according to DSTU 6024:2008;

- myristic acid according to DSTU 4830:2007;

- lauric acid according to DSTU 4830:2007;

- linoleic acid according to DSTU 6024:2008;

- linolenic acid according to DSTU 4830:2007;

- sodium hydroxide according to GOST 4328.

Salts of fatty acids (soaps) are obtained by saponification samples of refined sunflower, palm kernel, coconut oil, as well as a number of fatty acids with sodium hydroxide, separating fatty acids from the mixture and further saponification them. For planning the experiment and data processing, mathematical methods were applicated, the software packages of Missrosoft Excel and Statistica [11, 12] were used.

Results of work. The solubility of sodium salts of fatty acids obtained in a three-component neutralizing solution at different temperatures was investigated. The results of research data are presented in Figure 1. 


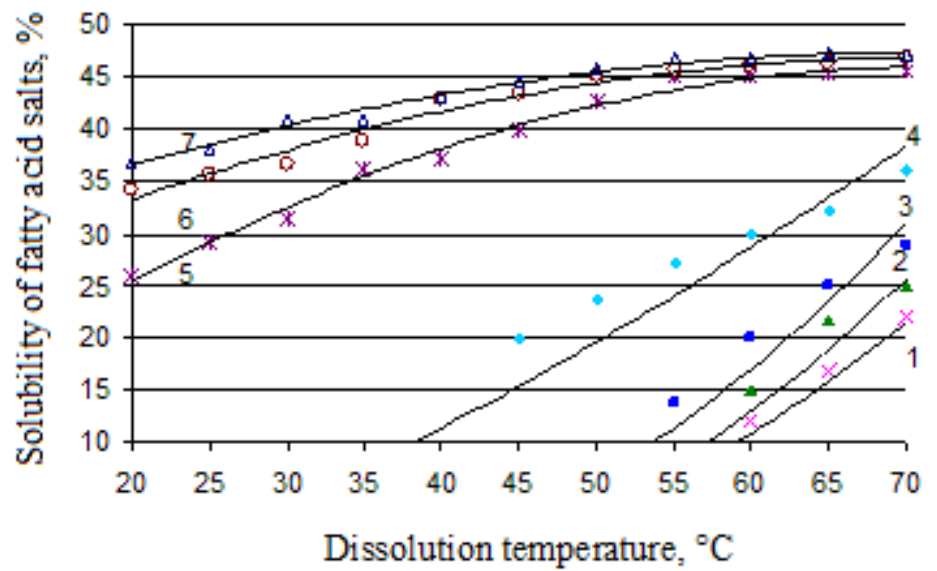

Fig. 1. The limiting solubility dependence of soaps of stearin (1), palmitic (2), myristic (3), lauric (4), oleic (5), linoleic (6) and linolenic (7) fatty acids at the base of the neutralizing solution from temperature.

Analyzing the graphical descriptions of the dependences of the solubility of the soaps of stearin, palmitic, myristic, lauric, oleic, linoleic and linolenic fatty acids on the basis of the neutralizing solution from the temperature, we can conclude that the decoupling of the solubility of fatty acid salts in the basis of the neutralizing solution is the molecular mass of the fat acids and the degree of unsaturation of its molecule.

The results of investigations of the marginal solubility of sodium salts (soaps) of fatty acids of individual oils in the basis of the neutralizing solution from the dissolution temperature are shown in Figure 2. The decisive value in the degree of solubility of the sodium salts of fatty acids of individual oils in the basis of the neutralizing solution are the structure and ratio of fatty acids included in the composition of the oil, and, consequently, the melting point of the oils.

Based on the research results, the solubility of soap fatty acids of the studied oil series at the base of the neutralizing solution at a temperature of $60-70{ }^{\circ} \mathrm{C}$ varies from $25 \%$ (for palm oil) to $47 \%$ (for sunflower and soybean oils), which exceeds that in water in 2,5 - 4,7 times.

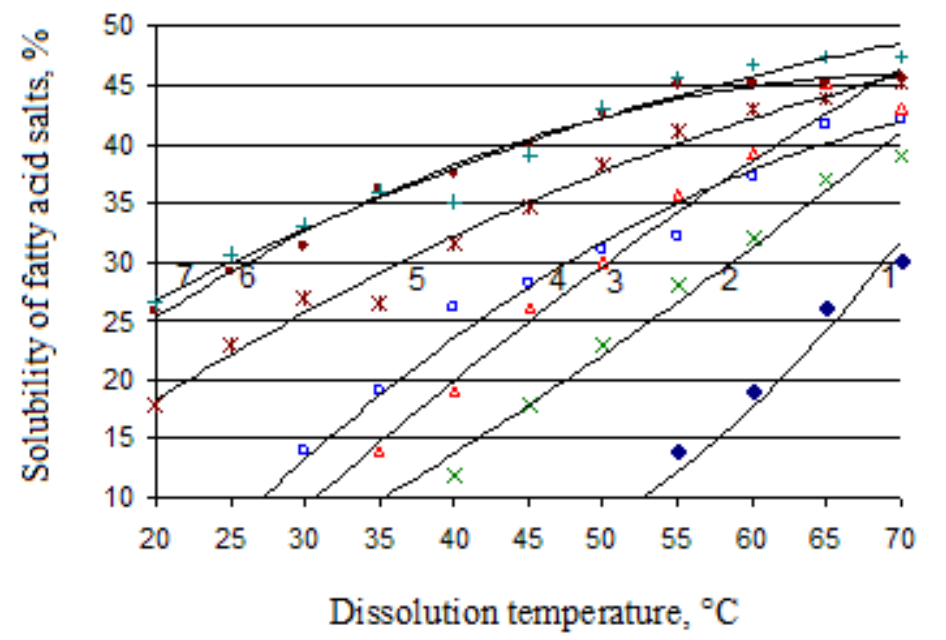

Fig. 2. The limiting solubility dependence of soaps of palm stearin (1), palm (2), coconut (3), palm kernel (4) oils, palm olein (5), sunflower (6) and soybean (7) oils in the base of the neutralizing solution from temperature.

\section{Conclusions}

1. The recommendations on the solubility of sodium salts of fatty acids and their mixtures in the neutralizing solution are substantiated, namely: the limiting solubility of the salts of the indicated fatty acids 
and their mixtures occurring in the specified oils in the neutralizing solution at a temperature of $60-65{ }^{\circ} \mathrm{C}$ fluctuates within from 25 to $47 \%$; limit solubility of soap of fatty acids in the given range of temperatures in the basis of the neutralizing solution exceeds that in water by 2,5-4,7 times. 2. It is proposed to use concentrated soapstocks after the neutralization of oils and fats in a neutralizing solution of a substantiated composition after further treatment as a liquid toilet soap. Moreover, the concentration of soapstock in it (in terms of fatty acids) should be about $20 \%$ (in accordance with the requirements of the regulatory documentation for liquid soap).

\section{Bibliography}

1. Arutiunian N.S., Kornena E.P., Nesterova E.A., Arutiunian N.S. (2004). Rafynatsyia masel y zhyrov. Teoretycheskye osnovi, praktyka, tekhnolohyia, oborudovanye. SPb.: HYORD. 288 p. [In Russian].

2. Crengros J. (1994). The refining of sunflower oil. J. Oil \& Fats International. 6. P. 19-23.

3. Leibovitz Z., Rucnenstein C. (1991). New processes in degumming, bleaching, deacidification deodorezation and winterizing of adible oils. Revue France Corps gras. 7/8. P. 303-308.

4. Pat. 2258734 RF C11B3/00 Sposob rafinacii rastitel'nogo masla. SHevchenko V.M., Hudolej V.I., Isaeva V.V. i dr. ZAO «Rabochij». № 2004124025/13. zayavl.: 10.08.2004, opubl.: 20.08.2005. [In Russian].

5. Dijkstra Albert J., Martin Van Opstal. (1998). The total degumming process J. Amer. Oil Chem. Soc. v.66. 7. C. $1002-1009$.

6. Lyvynskyi A.A. (2005). Tendentsyy razvytyia tekhnolohyy rafynatsyy y oborudovanyia dlia ee osushchestvlenyia v otechestvennoi praktyke. A.A. Lyvynskyi. Otraslevie vedomosty. Masla y zhyry. 11. P. 16-17. [In Russian].

7. Koshkarev Y.A. (2002). Tendentsyy razvytyia proyzvodstva podsolnechnykh rafynyrovannykh rastytelnykh masel. Maslozhyrovaia promyshlennost. 3. P. 14-16. [In Russian].

8. Petik I.P., Hladkyi F.F., Fediakina Z.P., Bielinska A.P., Filenko L.M. (2011). Vplyv komponentnoho skladu osnovy neitralizuiuchoho rozchynu na yoho kharakterystyky. Visnyk Natsionalnoho tekhnichnoho universytetu «Kharkivskoho politekhnichnoho instytutu». Kharkiv: NTU «KhPI». № 58. P. 31-35. [in Ukrainian].

9. Petik I.P., Hladkyi F.F., Fediakina Z.P., Bielinska A.P. (2012). Sklad osnovy neitralizuiuchoho rozchynu yak faktor efektyvnosti rafinatsii olii ta zhyriv. Tekhnichni nauky: stan, dosiahnennia i perspektyvy rozvytku m'iasnoi, oliiezhyrovoi ta molochnoi haluzei: materialy Mizhnarodnoi nauk.-tekhn. konf., 22-23 bereznia, 2012 r. / orhkomitet: A.I. Ukrainets (holova). Kyiv: NUKhT. P. 108. [in Ukrainian].

10. Petik I.P. (2013). Znyzhennia vmistu produktiv okysnennia $v$ oliiakh, yaki proishly neitralizatsiiu $v$ rozchyni, shcho mistyt etanol. Visnyk Natsionalnoho tekhnichnoho universytetu «Kharkivskoho politekhnichnoho instytutu». Kharkiv: NTU «KhPI». №16 (989). P.150-152. [in Ukrainian].

11. Obrabotka эksperymentalnыkh dannыkh [Elektronnyi resurs] / B. D. Ahapev, V.N. Belov, F. P. Kesamanly y dr. - Sankt-Peterburh : Yzd-vo SPbHTU, 2001. - Rezhym dostupa : http://users.kpi.kharkov.ua/fmp/biblio/ BOOK1/ ref.html. [In Russian].

12. Elyseeva Y. Y. Obshchaia teoryia statystyky [Tekst]: Uchebnyk / Y.Y. Elyseeva, M. M. Yuzbashev [pod red. Y. Y. Elyseevoi]. - 5-e yzd., pererab. y dop. - M. : Fynansy y statystyka, 2004. - 656 s. [In Russian]. 